\title{
Analisis Kendala-kendala yang dihadapi Satuan Pengawasan Internal dalam membangun Zona Integritas di RSUP Prof. Dr. R. D Kandou Manado
}

\author{
MERCEL HENDRIK LAHIANG ${ }^{1}$, LINTJE KALANGI ${ }^{2}$, LINDA LAMBEY ${ }^{3}$ \\ ${ }^{123}$ Program Magister Akuntansi, Fakultas Ekonomi dan Bisnis Universitas Sam Ratulangi \\ email: mrclynti63@yahoo.com¹, lintje_kalangi@yahoo.com², lindalambey@yahoo.com ${ }^{3}$
}

\begin{abstract}
Absrtract. This study aims to analyze the obstacles experienced by Internal Auditor on Integrity Zone Development at Prof. Dr. R. D. Kandou Manado General Hospital. This is a qualitative research with exploratory approach. Data were obtained by in-depth interviews, observation and documentation study. Key informants were determined by purposive sampling. Triangulation techniques were used to test the validity of data and data sources. The data were transcribed from the interviews transcriptions. They were analyzed by analytical methods consisting of the theme/coding, conceptualizing scientific statements and interpreting them in narrative form. The results show that there are some obstacles experienced by Internal Auditor. These obstacles are (1) inadequate competences. These in-competencies influence the overall capabilities of Internal Auditor; (2) complexity of working environment. This complexity influences Auditor's independency in decision making and or executing their main tasks and functions; (3) problems in budgeting in terms of lack of budget allocation in improving human resources ability; (4) lack of committed human resources and in their participation in auditing activities and programs; (5) management policy that reduce internal auditor authority, (6) dual position. Auditors have dual position in organizational structure. Hence they do not perform well their main tasks and functions. On the other hand, efforts done to solve those problems are (1) to conduct consultation and coordination with Inspectorate General of Ministry of Health and (2) to implement Risk Based Audit in the hospital in order to improve its control and supervision, (3) continuous socialization. Because of importance of internal auditor role and function on Integrity Zone Development, and their important roles as an internal controller and supervisor, therefore it is necessary to improve the SPI human resources through education, training, workshop, and seminar, especially in audit. It is hoped that their improvement significantly influence the public services.
\end{abstract}

Keywords: Integrity Zone, Internal Auditor, Capabilities, role and function

Abstrak. Penelitian ini bertujuan untuk menganalisis kendala-kendala yang dihadapi oleh Satuan Pengawasan Internal RSUP Prof. Dr. R. D. Kandou Manado pada pembangunan Zona Integritas sekaligus menggali upaya-upaya yang sudah dilakukan oleh SPI dalam mengatasi kendala tersebut. Penelitian ini menggunakan metode kualitatif dengan pendekatan eksploratori. Data diperoleh melalui teknik wawancara mendalam, observasi dan studi dokumentasi. Informan kunci ditetapkan secara purposive sampling dengan memenuhi kriteria yang ditetapkan untuk mendapatkan informasi yang tepat dan akurat. Teknik triangulasi digunakan untuk menguji validitas data dan sumber data. Data transkrip yang diuraikan dari hasil wawancara dianalisis menggunakan metode analisis yang terdiri dari pemberian tema/coding, konseptualisasi pernyataan ilmiah dan menginterpretasikannya dalam bentuk narasi. 
Hasil penelitian menunjukkan bahwa terdapat kendala-kendala yang mendasar yang dihadapi oleh SPI dalam pembangunan Zona Integritas. Kendala tersebut adalah (1) kompetensi yang tidak memadai mempengaruhi kapabilitas SPI secara keseluruhan, (2) ruang lingkup kerja yang kompleks sehingga berpengaruh pada independensi dalam pengambilan keputusan atau menjalankan tugas pokok dan fungsi secara keseluruhan, (3) kemudian permasalahan anggaran, dalam arti, kurangnya alokasi anggaran pada peningkatan kemampuan sumber daya manusia di SPI, (4) komitmen organisasi yang belum terlihat dari semua unsur di rumah sakit, (5) kebijakan manajemen atas pengangkatan dan pemberhentian personil SPI menjadikan kewenangan SPI berkurang, (6) rangkap jabatan yang membuat implementasi tugas pokok dan fungsi SPI menjadi tidak maksmimal. Namun demikian sudah ada beberapa upaya yang dilakukan oleh SPI dalam mengatasi kendala-kendala tersebut seperti (1) melakukan konsultasi dan koordinasi dengan pembina SPI yaitu Inspektorat Jenderal Kementerian Kesehatan, serta (2) mencoba menerapkan Audit Berbasis Risiko di rumah sakit, (3) sosialisasi program yang terus menerus, dengan harapan akan lebih membantu pelaksanaan pengendalian dan pengawasan yang dilakukan. Karena begitu pentingnya peran dan fungsi SPI pada pembangunan Zona Integritas khususnya, serta peran mereka sebagai pengendali dan pengawas internal maka perlu adanya peningkatan kualitas sumber daya SPI melalui pelatihan, pendidikan serta workshop atau seminar tentang audit internal, sehingga pada akhirnya akan memberikan juga kontribusi signifikan terhadap kualitas layanan publik.

Kata kunci: Zona Integritas, SPI, kapabilitas, peran dan fungsi

\section{Pendahuluan}

Reformasi birokrasi adalah langkah awal dalam implementasi penataan sistem penyelenggaraan pemerintahan yang baik, efektif dan efisien, sehingga dapat melayani masyarakat secara cepat, tepat, dan profesional. Perlu dilakukan reformasi birokrasi pada semua sektor termasuk sektor pelayanan publik karena reformasi birokrasi masih menjadi isu yang kuat diperbincangkan.

Semua unsur terkait dalam suatu entitas atau organisasi, baik swasta maupun pemerintah, harus terlibat dalam reformasi birokrasi. Demikian pula di rumah sakit, semua pihak harus terlibat langsung dan tidak langsung dalam mewujudkan tata kelola dan pelayanan publik yang baik. Artinya siapapun yang menjadi bagian dari rumah sakit turut serta mengambil bagian dalam reformasi birokrasi. Masih terdapat keluhan dari masyarakat luas terhadap layanan kesehatan, khususnya layanan kesehatan yang diberikan oleh rumah sakit. Pelayanan yang lambat, pemungutan dana liar atas pasien dengan jaminan, sarana dan prasarana yang kurang lengkap, masih kerap terdengar. Hal itu dapat saja terjadi karena kurangnya tenaga kesehatan, kurangnya anggaran untuk sarana dan prasarana rumah sakit, serta diperburuk oleh lemahnya pengawasan dan pengendalian internal dalam organisasi tersebut dan ditambah lagi dengan faktor-faktor independensi, serta komitmen dari aparat pengawas internal. Contoh lain terhadap adalah lemahnya pengawasan terhadap pemberian resep obat oleh dokter. Sesuai dengan clinical pathway atau standar pelayanan yang harus diimplementasikan pada setiap pasien, ada standar obat atau bahan habis pakai lainnya yang digunakan dalam penanganan suatu tindakan medis. Obat harus sesuai dengan formularium nasional. Tetapi sering ada oknum dokter yang memberikan resep obat diluar formularium nasional, dengan harga yang lebih mahal dari obat dasar formularium. Obat tersebut diresepkan pada merek atau paten tertentu, dengan kompensasi "janji” mendapatkan sesuatu dari peresepan tersebut yang dijanjikan oleh distributor atau pabrikan obat. 
Rumah Sakit Umum Pusat (RSUP) Prof.Dr.R.D. Kandou Manado adalah salah satu entitas publik dan satuan kerja pemerintah pusat di bawah naungan Kementerian Kesehatan. Rumah Sakit ini adalah Rumah Sakit Pendidikan dengan Tipe A yang juga bekerjasama dalam hal pendidikan kesehatan dengan Universitas Sam Ratulangi Manado. Pada tahun 2007 RSUP Prof.Dr.R.D Kandou Manado telah disahkan oleh Kementerian Keuangan RI sebagai Rumah Sakit yang menerapkan Pola Pengelolaan Keuangan Badan Layanan Umum, dimana efisiensi dan produktifitas menjadi prinsip pokok dalam Badan Layanan Umum.

Pada tahun 2016, RSUP Prof.Dr.R.D. Kandou Manado, mengelola anggaran sebesar Rp. 706.897.881.000 (tujuh ratus enam milyar delapan ratus sembilan puluh tujuh juta delapan ratus delapan puluh satu ribu rupiah) terdiri dari sumber anggaran dari APBN sebesar Rp.296.064.490.000 serta Pendapatan Negara Bukan Pajak (PNBP) yang digunakan langsung - sehubungan dengan status pengelolaan keuangan Badan Layanan Umum, sebesar Rp.410.833.391.000 (data pagu dan realisasi anggaran RSUP Prof.Dr.R.D. Kandou Manado, per 31 Desember 2016). Melihat besarnya anggaran yang dikelola oleh rumah sakit, pertanggung jawaban pengelolaan keuangan, baik dari perencanaan anggaran, pelaksanaan anggaran dan pelaporannya tentu membutuhkan suatu tata kelola yang baik, karena dengan anggaran sebesar itu, potensi penyimpangan yang dapat saja terjadi. Pengawasan berfungsi membantu agar sasaran yang ditetapkan organisasi dapat tercapai, di samping itu pengawasan berfungsi mendeteksi secara dini terjadinya penyimpangan pelaksanaan, penyalahgunaan wewenang, pemborosan dan kebocoran (Sukriah, dkk 2009). Paradigma pengawasan lama sebagai watchdog yang dilakukan oleh Aparat Pengawasan Intern Pemerintah (APIP), telah berubah menjadi konsultan dan quality assurance membawa konsekuensi terhadap penambahan tugas dan tanggung jawab APIP saat ini. Presiden menargetkan paling tidak 85\% APIP Kementerian Negara/Lembaga dan APIP Daerah ditargetkan memperoleh predikat level 3 (Integrated) Internal Audit Capability Model (IACM) di tahun 2019. Berdasarkan hasil penilaian tingkat kapabilitas pada 474 APIP Kementerian, Lembaga, dan Pemerintah daerah per 31 Desember 2014, sebanyak 404 APIP atau 85,23\% berada pada Level-1, 69 APIP atau 14,56\% Level-2, dan baru 1 APIP atau 0,21\% yang berada pada Level-3 (BPKP Pusat, 2014). Dengan adanya komitmen pemerintah untuk mewujudkan good governance khususnya pemberantasan korupsi, kolusi dan nepotisme, serta meningkatkan kinerja pelayanan publik, maka kinerja atas penyelenggaraan organisasi pemerintah menjadi perhatian pemerintah untuk dibenahi, salah satunya melalui sistem pengawasan yang efektif, dengan meningkatkan peran dan fungsi dari Aparat Pengawas Intern Pemerintah dengan kata lain peran dan fungsi APIP menjadi penting dalam kaitannya dengan pembangunan Zona Integritas.

\section{Metode Analisis}

Penelitian ini akan menggunakan metode penelitian kualitatif dengan pendekatan studi kasus yang menggunakan teknik dalam pengumpulan data melalui wawancara, studi dokumentasi dan observasi. Peneliti ingin menggali informasi secara mendalam tentang kendala-kendala yang menghambat SPI dalam penerapan SPI dan program pembangunan Zona Integritas dan pelaksanaan tugas serta kegiatannya.

\section{Metode Penelitian}

Penelitian ini dilakukan dengan menggunakan metode penelitian kualitatif dengan tujuan untuk memahami fenomena tentang apa yang dialami oleh subjek penelitian misalnya perilaku, persepsi, motivasi, tindakan, dan lain-lain. (Koentjaraningrat, 1993:89). Penentuan metode penelitan secara kualitatif dalam penelitian ini disebabkan oleh beberapa hal yaitu, pertama, metode ini dianggap dapat menjelaskan dan menguraikan gambaran peran dan 
fungsi dari Satuan Pengawasan Intern Rumah Sakit, baik dari segi personal maupun tugas pokok serta kewenangannya. Kedua, metode ini sangat membantu peneliti dalam mengumpulkan data yang relevan secara langsung dan arti serta makna dibalik data yang diperoleh melalui wawancara langsung dan sekaligus juga diharapkan peneliti dapat menemukan upaya dalam mengatasi kendala-kendala yang dihadapi. Ketiga, memastikan kebenaran atau keabsahan data yang diperoleh menggunakan uji keabsahan data dengan menggunakan teknik triangulasi.

Penelitian ini juga menggunakan metode kualitatif studi kasus yang menurut Pollit dan Hungler (1990) menjelaskan bahwa fokus studi kasus terletak pada penentuan dinamika mengenai pertanyaan lebih lanjut mengapa seseorang berpikir, melakukan sesuatu, atau bahkan mengembangkan diri. Fokus ini dinilai oleh Pollit dan Hungler penting dalam studi kasus karena dibutuhkan analisis yang intensif, bukan berfokus pada status, kemajuan, tindakan, atau pikiran yang dimilikinya.

Penggunaan penelitian metode studi kasus ini disebabkan oleh karena peneliti ingin memahami bagaimana peran setiap individu, kebijakan, kewenangan masing-masing personil, kendala apa yang dihadapi oleh personal SPI dalam menjalankan tugasnya, atau bahkan motivasi apa yang mendukung dan tidak mendukung pelaksanaan tugas SPI dalam ruang lingkup kerja yang besar.

Perilaku individu menurut Gibson adalah:

(a) perilaku timbul karena ada stimulus atau motivasi,

(b) perilaku diarahkan kepada tujuan,

(c) perilaku yang terarah pada tujuan dapat terganggu oleh frustasi, konflik, dan kecemasan.

Lewat studi kasus atas peran dan fungsi pengawasan atau kegiatan lain SPI di RSUP Prof. Dr. R. D. Kandou, maka kendala-kendala yang menghambat implementasi tugas pokok dan fungsi SPI dapat diketahui. Disamping menemukan dan menguraikan kendala-kendala yang dihadapi, pendekatan studi kasus berusaha menemukan tindak lanjut berupa perbaikan atau upaya yang perlu dilakukan untuk mengatasi kendala yang dihadapi dalam pelaksanaan tugas pokok dan fungsi SPI serta peran mereka dalam reformasi birokrasi serta penerapan good governance yang akan membantu rumah sakit dalam pencapaian pembentukan Zona Integritas. Tindak lanjut berupa perbaikan ini ditujukan bagi RSUP Prof. Dr. R. D. Kandou Manado khususnya bagi SPI dalam rangka meningkatkan kapabilitas dan kompetensi mereka.

\section{Analisis}

Penelitian ini dilakukan selama 5 (lima) bulan sejak bulan Nopember 2017 sampai Maret 2018 dengan cara melakukan wawancara yang disesuaikan dengan pedoman wawancara kepada informan dengan menggunakan alat bantu rekam untuk merekam seluruh isi wawancara, serta menggunakan instrumen pendukung antara lain buku catatan, alat perekam berupa audio, kamera dari smartphone untuk mendokumentasikan kegiatan wawancara serta laptop untuk mengetik hasil penelitian, termasuk data transcription dan coding.

\section{Peran Strategis Satuan Pengawasan Internal}

Sebagai instansi pemerintah, RSUP Prof. Dr. R. D. Kandou Manado perlu meningkatkan dan terus mengembangkan pelayanan publik mengingat fungsi utama pemerintah adalah melayani masyarakat maka pemerintah perlu terus berupaya meningkatkan kualitas pelayanan publik (Menteri PAN dalam Frederik Mote, 2008). 
WBK adalah singkatan dari Wilayah Bebas Korupsi. WBK adalah predikat yang diberikan kepada suatu unit kerja yang memenuhi sebagian besar manajemen perubahan, penataan tatalaksana, penataan sistem manajemen SDM, penguatan pengawasan, dan penguatan akuntabilitas kinerja. WBBM adalah singkatan dari Wilayah Birokrasi Bersih Melayani. WBBM adalah predikat yang diberikan kepada suatu unit kerja yang memenuhi sebagian besar manajemen perubahan, penataan tatalaksana, penataan sistem manajemen SDM, penguatan pengawasan, penguatan akuntabilitas kinerja, dan penguatan kualitas pelayanan publik.

Tahap pembangunan Zona Integritas adalah sebagai berikut:

1. Pencanangan Zona Integritas berupa penanda tanganan pakta integritas oleh seluruh atau sebagian pegawai, kemudian diikuti dengan membuat pernyataan komitmen membangun Zona Integritas.

2. Pembangunan Zona Integritas dengan menetapkan Unit Kerja yang akan diusulkan menjadi WBK dan WBBM.

3. Pengusulan dimana dilakukan penilaian mandiri yang dilakukan oleh Tim Penilai Internal, dalam hal ini Inspektorat Jenderal Kementerian Kesehatan RI, yang kemudian akan melaporkan hasil penilaian kepada pimpina instansi.

4. Reviu Tim Penilai Nasional yang terdiri Komisi Pemberantasan Korupsi (KPK), Kementerian PAN-RB, dan Ombudsman RI.

5. Penetapan WBK dan WBBM dimana Menteri PAN-RB mengusulkan kepada kementerian terkait agar unit kerjanya ditetapkan sebagai WBK dan WBBM.

6. Pembinaan dan Pengawasan. Pembinaan dilakukan oleh kementerian atau instansi terkait sedangkan untuk pengawasan dilakukan oleh kementerian PANRB.

Kerangka penilaian pembangunan Zona Integritas terdiri dari 2 (dua) faktor yaitu faktor pengungkit dan hasil. Faktor Pengungkit memiliki nilai $60 \%$ dan faktor hasil $40 \%$.

Faktor Pengungkit adalah Manajemen Perubahan dimana ada Penataan Tata Laksana, Penataan Sistem Manajemen SDM, dan Penguatan Akuntabilitas Kinerja serta Penguatan Pengawasan. Di sinilah peran strategis SPI di rumah sakit.

\section{Kendala-kendala yang dihadapi SPI RSUP Prof. Dr. R. D. Kandou Manado pada Pembangunan Zona Integritas:}

Terdapat beberapa kendala yang ditemukan dalam penelitian ini yaitu: 1) kompetensi yang tidak memadai; 2) komitmen organisasi; 3) anggaran; 4) lingkungan kerja; 5) kebijakan manajemen dan 6) rangkap jabatan.

Kendala pertama yang menjadi kendala utama yaitu kompentensi yang tidak memadai. Kompetensi auditor adalah kualifikasi yang dibutuhkan oleh auditor untuk melaksanakan audit dengan benar (Rai dalam Ika Sukriah dkk., 2009). Dalam melakukan audit, seorang auditor harus memiliki mutu personal yang baik, pengetahuan yang memadai, serta keahlian khusus di bidangnya. Kompetensi berkaitan dengan keahlian profesional yang dimiliki oleh auditor sebagai hasil dari pendidikan formal, ujian profesional maupun keikutsertaan dalam pelatihan, seminar, dan simposium (Suraida dalam Ika Sukriah dkk., 2009). Kompetensi yang dimiliki oleh seorang auditor di bidang auditing ditunjukkan oleh latar belakang pendidikan dan pengalaman yang dimilikinya. Dari sisi pendidikan, idealnya seorang auditor memiliki latar belakang pendidikan (pendidikan formal atau pendidikan dan latihan sertifikasi) dibidang auditing. Sedangkan pengalaman, lazimnya ditunjukkan oleh lamanya yang bersangkutan berkarir di bidang audit atau intensitas/sering dan bervariasinya melakukan audit. Auditor yang mengaudit laporan keuangan harus memiliki latar belakang pendidikan dan memahami dengan baik proses penyusunan laporan 
keuangan dan standar akuntansi yang berlaku. Demikian pula dengan auditor yang melakukan audit operasional dan ketaatan, dia harus memiliki pengetahuan yang cukup mengenai kegiatan operasional yang diauditnya, baik cara melaksanakannya, maupun kriteria yang digunakan untuk melakukan penilaian (Tim Penyusun Modul Program Pendidikan Non Gelar Auditor Sektor Publik Sekolah Tinggi Akuntansi Negara, Badan Pendidikan dan Pelatihan Keuangan (BPPK), Departemen Keuangan Republik Indonesia, Yayasan Pendidikan Internal Audit (YPIA); Dasar-dasar Audit Internal Sektor Publik, 2010). Seorang auditor pemerintah haruslah memiliki dasar pengetahuan dalam memahami entitas yang diaudit yang dengan sendirinya akan membantu mereka dalam pelaksanaan audit itu sendiri. Pengetahuan tersebut mencakup kemampuan melakukan reviu, teori organisasi pengetahuan dasar audit dan pengetahuan tentang entitas sektor publik, termasuk di dalamnya pengetahuan tentang ilmu akuntansi dalam rangka membantu auditor internal melakukan reviu terhadap laporan keuangan entitas. Seorang auditor juga harus bisa menampilkan sikap yang profesional dengan memiliki pengetahuan dasar tersebut untuk hasil kerja yang efektif. Kompleksnya organisasi dan kegiatan di suatu entitas, rumah sakit misalnya, menjadi sebuah tantangan tersendiri bagi auditor internal dalam melaksanakan tugas pokok dan fungsinya.

Kendala kedua yaitu komitmen organisasi. Seperti intisari dari Sistem Pengendalian Internal Pemerintah (SPIP) adalah komitmen dari pimpinan dan seluruh jajarannya, demikian pula dengan pembangunan Zona Integritas, dibutuhkan komitmen organisasi yang kuat. Komitmen organisasi yang lemah akan berpengaruh pada hasil kerja SPI itu sendiri.

Komitmen organisasi didefinisikan sebagai orientasi hubungan aktif antara individu dan organisasinya, orientasi hubungan tersebut mengakibatkan individu atas kehendak sendiri bersedia memberikan sesuatu demi merefleksikan dukungannya bagi tercapainya tujuan organisasi (Amin Wahyudi, 2012). SPI RSUP Prof. Dr. R. Kandou Manado telah merancangkan program kerja pengawasan mereka dan mensosialisasikannya ke seluruh unit kerja di rumah sakit, termasuk program dalam rangka pembangunan Zona Integritas. Diperlukan pula dukungan dan keterlibatan semua unsur di rumah sakit, dalam arti apa yang sudah diprogramkan oleh manajemen termasuk oleh SPI harus direalisasikan. Komitmen organisasi dalam mewujudkan Wilayah Bebas Korupsi dan Wilayah Birokrasi Bersih Melayani menjadi sangat penting di bawah pengawasan SPI tentunya.

Kendala yang ketiga adalah alokasi anggaran yang masih kurang, dalam hal anggaran untuk pembiayaan pengembangan sumber daya manusia di SPI. RSUP Prof. Dr. R. Kandou Manado adalah entitas sektor publik dan dengan demikian mengelola anggaran sektor publik. Menurut Mardiasmo dalam Irfan Fatoni dan Indah Dewi Nurhayati (2013) menyatakan bahwa anggaran sektor publik merupakan alat pemerintah untuk mengarahkan pembangunan menjamin kesinambungan dalam rangka meningkatkan kualitas hidup masyarakat. Anggaran diperlukan karena keinginan dan kebutuhan masyarakat yang tak terbatas dan terus berkembang, sumber daya yang terbatas, dan anggaran merupakan instrumen pelaksanaan akuntabilitas publik oleh instansi atau lembaga pemerintah. Halim dalam Irfan Fatoni Indah Dewi Nurhayati (2013) menyatakan bahwa Anggaran bagi pemerintah merupakan alat perencanaan, alat kebijakan, alat politik, alat koordinasi dan komunikasi, alat penilaian kerja, alat motivasi, dan alat menciptakan ruang publik. Definisi lainnya tentang anggaran bahwa anggaran adalah penguhubung antara perencanaan dan pengendalian dimana merupakan perwujudan komitmen untuk mengimplementasikan berbagai perencanaan dan pengendalian, perencanaan jangka pendek dan jangka menengah yang secara jelas memuat apa yang harus dikerjakan dan sumber daya yang diperlukan selama satu tahun (Jones dan Pendlebury dalam Kewo dkk. 2017). 
Beberapa teori di atas menjelaskan pentingnya anggaran dan alokasinya terhadap suatu entitas atau organisasi dalam mencapai tujuan organisasi tersebut. Hubungannya dengan kinerja auditor adalah bahwa anggaran juga dialokasikan untuk kegiatan pengembangan sumber daya manusia termasuk meningkatkan kompetensi auditor internal yang pada akhirnya akan memperkuat sistem pengendalian karena personil auditor internal yang kuat, dan memiliki kompetensi yang memadai.

Lingkungan kerja menjadi kendala yang keempat dalam penelitian ini. Lingkungan kerja auditor internal yang kompleks, dalam arti sumber daya manusia, yang terdiri dari tenaga medis berupa dokter, perawat, apoteker, teknik listrik, tenaga fisika medik, tenaga radiologi, memberikan kendala tersendiri terhadap pencapaian tujuan organisasi, dalam konteks penelitian ini yaitu pembangunan Zona Integritas. Hal ini akan berpengaruh terhadap hasil pengawasan yang dilakukan oleh SPI. Hubungan kerja antara auditor dengan auditi, atau dapat dikatakan hubungan kolega sebagai rekan sejawat akan membawa pengaruh terhadap independensi auditor. Selain komitmen dari manajemen di rumah sakit, komitmen juga harus datang dari semua unsur rumah sakit termasuk rekan sejawat, yang adalah kolega dari personil SPI. Tanpa melihat hubungan kolega, setiap unsur di rumah sakit harus ikut ambil bagian dengan partisipasi aktif dalam setiap kegiatan dan program SPI. Dan tak kalah pentingnya adalah komitmen dari personil SPI itu sendiri terhadap organisasi dan kedudukan mereka sebagai internal auditor. Independensi harus ditegakkan atas dasar pengendalian dan pengawasan internal yang baik tanpa terpengaruh oleh lingkungan kerja mereka. Salah satu sikap yang perlu diimplementasikan oleh auditor internal, dalam hal ini SPI rumah sakit adalah independen. Selanjutnya adalah kendala kelima yaitu kebijakan manajemen. Kebijakan pengangkatan dan pemberhentian personil SPI di rumah sakit oleh pimpinan rumah sakit memberikan kesan bahwa apabila SPI tidak bisa bekerja sama, dalam arti mengikuti atau menuruti kebijakan pimpinan maka personil tersebut dapat berhentikan atau dimutasikan setiap waktu, sehingga personil SPI direkrut dari internal rumah sakit sendiri, dengan kata lain, bila SPI dari internal rumah sakit, maka lebih mudah menjabarkan kebijakan, baik kebijakan secara umum dalam organisasi, maupun kebijakan khusus terkait program dan kegiatan SPI. Carl J. Federick sebagaimana dikutip Taufiqurahman (2014) mendefinisikan kebijakan sebagai serangkaian tindakan/kegiatan yang diusulkan seseorang, kelompok, atau pemerintah dalam suatu lingkungan tertentu di mana terdapat hambatan-hambatan (kesulitan-kesulitan) dan kesempatan-kesempatan terhadap pelaksanaan usulan kebijaksanaan tersebut dalam rangka mencapai tujuan tertentu. Solichin Abdul Wahab dalam Taufiqurahman (2014) mengemukakan bahwa istilah kebijakan sendiri masih menjadi silang pendapat dan untuk memahami istilah kebijakan Solihin Abdul Wahab memberikan beberapa pedoman antara lain:

a. Kebijakan harus dibedakan dari keputusan;

b. Kebijakan sebenarnya tidak serta merta dapat dibedakan dari administrasi;

c. Kebijakan mencakup perilaku dan harapan-harapan;

d. Setiap kebijakan memiliki tujuan atau sasaran tertentu;

e. Kebijakan meliputi hubungan yang bersifat antar dan intra organisasi.

Pengangkatan dan pemberhentian personil SPI di RSUP Prof. Dr. R. D. Kandou Manado adalah kewenangan Direktur Utama. Kebijakan pengangkatan dan pemberhentian SPI di rumah sakit mengacu pada Permenkes 1045 tahun 2006 tentang pedoman organisasi rumah sakit khususnya pada Bab V bagian pertama tentang Satuan Pengawas Intern dimana pada ayat 3 jelas dicantumkan bahwa SPI dibentuk dan ditetapkan oleh pimpinan rumah sakit, dalam hal ini direktur utama.

Kendala yang terakhir atau yang keenam yaitu permasalahan rangkap jabatan. Sesuai dengan standar profesi audit internal (SPPIA) nomor 1120 terkait dengan objektivitas 
individual yang menyatakan "internal auditors must have an impartial, unbiased attitude and avoid any conflict of interest". Hal ini diinterpretasikan bahwa rangkap tugas dan wewenang dapat berdampak pada pelaksanaan tugas dan tanggung jawab auditor internal karena gangguan yang ditimbulkan oleh kesibukan dan kompleksitas tugas sebagai tenaga fungsional kesehatan sehingga pada penelitian ini, kami menekankan kendala rangkap jabatan ini kepada hal konsentrasi atau fokus pelaksanaan tugas SPI yang terkendala dengan adanya tugas fungsional kepala dan staf SPI lainnya di rumah sakit, dimana kepala SPI juga aktif sebagai dokter spesialis dan sekretaris SPI juga menjabat sebagai sekretaris komite medik.

Menurut Banks dalam Riza Maulida (2015) rangkap jabatan yang menyebabkan kurangnya fokus, waktu dan energi sehingga seseorang tidak dapat bertindak sebagai agen yang efektif. Banks juga mengungkapkan bahwa hal tersebut merupakan bagian dari kegagalan yang biasa terjadi dalam proses tata kelola. Kesibukan personil SPI dalam melaksanakan kegiatan dan program SPI, juga akan bertambah dengan pekerjaan lainnya. Rangkap jabatan juga dapat menyebabkan kurangnya independensi dan memicu konflik kepentingan. Kurangnya independensi dapat terjadi jika personil SPI merangkap sebagai ketua komite (keperawatan), atau tugas fungsional lainnya sebagai seorang praktisi (dokter, perawat). Sedangkan konflik kepentingan dapat muncul dikarenakan tumpang tindihnya program komite dan program.

\section{Upaya yang dilakukan untuk mengatasi kendala yang dihadapi oleh SPI pada pembangunan Zona Integritas.}

Dalam mengatasi kendala yang dihadapi oleh SPI tersebut, maka ada beberapa upaya yang dilakukan yaitu: 1) melakukan konsultasi dan koordinasi; 2) menerapkan audit berbasis risiko-risk based audit-di rumah sakit; 3) sosialisasi.

Upaya konsultasi dan koordinasi dilakukan dalam mengatasi kesulitan dan kendala keterbatasan kompetensi personil SPI. Konsultasi dan koordinasi dilakukan dengan pihak yang memiliki kompetensi serta kewenangan seperti Inspektorat Jenderal Kementerian Kesehatan sebagai pembina SPI, serta dengan auditor eksternal lainnya seperti Badan Pengawasan Pembangunan dan Keuangan Propinsi Sulawesi Utara untuk mendapatkan dukungan serta bantuan dalam mengatasi kendala. Penting bagi SPI untuk selalu berkomunikasi dengan Inspektorat Jenderal, karena hal ini memang sudah menjadi tugas dari Inspektorat Jenderal untuk melakukan pembinaan bagi auditor internal di dalam jajaran kementeriannya. Salah satu fungsi dari inspektorat jenderal adalah melaksanakan pengawasan internal di lingkungan kementerian terhadap kinerja auditor internal, baik berupa reviu atas kinerja satuan kerja secara umum maupun penilaian terhadap kinerja SPI, dalam hal ini SPI di rumah sakit. Dengan demikian dari hasil pengawasan khusus untuk SPI akan didapatkan nilai kinerja dari auditor internal di masing-masing satuan kerja, juga dengan pengawasan dan penilaian ini akan ditemukan kendala-kendala yang terjadi selama pelaksanaan audit internal oleh SPI. Fungsi Inspektorat Jenderal sebagai konsultan diharapkan dapat memberikan arah/petunjuk kepada suatu masalah agar pelaksanaan kebijakan/program/kegiatan tidak bertentangan dengan peraturan perundang-undangan yang berlaku. Dalam fungsi katalisator, Inspektorat Jenderal senantiasa mendorong/memacu terjadinya perubahan untuk mewujudkan tata kelola pemerintahan yang baik. Dengan fungsi quality assurance, Inspektorat Jenderal menerapkan sistem kendali mutu yang dimulai sejak tahap perencanaan, pengorganisasian dan pelaksanaan pengawasan (PMK nomor 6 tahun 2015, tentang Kebijakan Pengawasan Inspektorat Jenderal Kementerian Kesehatan RI).

Dengan adanya kebijakan tersebut di atas, SPI dapat memanfaatkannya melalui konsultasi dan koordinasi yang berkelanjutan sebagai upaya dalam mengatasi kendala pada 
pelaksanaan tugas pokok dan fungsi SPI serta memperkuat peran SPI pada pembangunan Zona Integritas.

Menurut Wang dan Fargher (2014), the coordination allows internal auditors to access the external auditors techniques, methods and terminology within the scope of internal auditing. Thus, the coordination is expected to help internal auditors improve their assurance-related work. Terjemahannya, bahwa koordinasi memberikan ruang kepada auditor internal untuk dapat mengakses atau mencontoh teknik, metode dan terminology yang digunakan auditor eksternal dalam ruang lingkup auditor internal itu sendiri jadi dengan koordinasi diharapkan dapat membantu auditor internal meningkatkan kemampuan mereka. Dalam kaitan dengan penelitian ini, auditor internal adalah SPI dan auditor eksternal adalah Inspektorat Jenderal Kementerian Kesehatan, Badan Pemeriksa Keuangan (BPK) atau juga Badan Pemeriksa Keuangan dan Pembangunan (BPKP). Setiap ada permasalahan dan kendala dalam pelaksanaan tugas SPI, maka semua unsur yang ada di SPI, baik Kepala, Sekretaris, dan koordinator serta staf, akan melakukan rapat koordinasi untuk mencari solusi bagi kendala. Hal ini dilakukan karena memang rencana audit dari auditor internal juga perlu dibahas bersama untuk memastikan bahwa bila ada kendala maka akan terkoordinasi. Rapat koordinasi tersebut perlu dijadwalkan sepanjang proses audit untuk segera memastikan kondisi pekerjaan audit serta kendala yang menyertainya dan akan segera mendapat penyelesaiannya secara efisien dan tepat waktu.

Upaya selanjutnya adalah SPI rumah sakit mencoba untuk menerapkan audit berbasis risiko. David M. Griffiths, PhD, FCA. (2006), mengatakan Audit Berbasis Risiko adalah suatu metode yang digunakan oleh departemen internal audit untuk menyediakan keyakinan bahwa risiko diatur agar berada dalam batas toleransi risiko perusahaan. Atau dengan kata lain, suatu proses yang mengelola risiko sampai pada suatu tingkat yang dipertimbangkan untuk dapat diterima oleh dewan direksi untuk bekerja secara efektif dan efisien. Audit Berbasis Risiko adalah suatu metode yang dapat memastikan bahwa manajemen risiko telah diimplementasikan sesuai dengan risk appetite yang dimiliki oleh organisasi, dalam hal ini rumah sakit, dimana risiko-risiko yang ada seperti di bidang pelayanan diaudit untuk mengetahui unit-unit mana yang memiliki risiko tinggi seperti instalasi gawat darurat, instalasi perawatan intensif, sehingga hasil audit ini dapat memberikan keyakinan kepada manajemen bahwa rumah sakit telah memiliki dan menjalankan manajemen risiko. Hal ini juga selaras dengan Standar Audit Intern Pemerintah Indonesia-3100-Sifat Kerja Audit Intern: Kegiatan Audit Intern harus dapat mengevaluasi dan memberikan kontribusi pada perbaikan tata kelola sektor publik, risk management, dan pengendalian intern dengan menggunakan pendekatan sistematis dan disiplin.

Yang terakhir adalah upaya sosialisasi. Menurut Depkes RI (2005) sosialisasi adalah penyebarluasan informasi (program, kebijakan, peraturan) dari satu pihak (pemilik program, kebijakan, peraturan) kepada pihak-pihak lain (aparat, masyarakat yang terkena program, dan masyarakat umum). Sedangkan menurut Sugiyana dalam Yesie Aprilia (2009), sosialisasi merupakan aktivitas komunikasi yang bertujuan untuk menciptakan perubahan pengetahuan, sikap mental, dan perilaku khalayak sasaran terhadap ide pembaruan (inovasi) yang ditawarkan. Sugiyana juga berpendapat bahwa sosialisasi adalah pengenalan dan penyebarluasan program kepada pihak lain yang memiliki kepentingan yang sama.

Basalamah dalam Pasca Rizki Dwi Ananda dkk. (2015) sosialisasi merupakan pembelajaran suatu nilai, norma dan pola perilaku, yang diharapkan oleh kelompok sebagai suatu bentuk reformasi sehingga menjadi organisasi yang efektif. Sosialisasi pembangunan Zona Integritas dilakukan bukan hanya pada bidang program dan rencana kegiatan SPI saja tetapi juga dilakukan dengan pendekatan audit berbasis risiko, yang memang belum semua pihak di rumah sakit yang memahami konsep tersebut, sehingga perlu juga dilakukan 
sosialisasi dengan tujuan untuk lebih memberi pengertian tentang pentingnya pengendalian intern dalam rangka program yang lebih besar di rumah sakit.

Sosialisasi diperlukan untuk memberikan pengertian dan pemahaman akan program yang ingin dilaksanakan untuk tujuan yang ingin dicapai. Dalam penelitian ini sosialisasi yang dimaksud adalah penyebarluasan informasi program Pembangunan Zona Integritas yang dilakukan oleh SPI rumah sakit sebagai salah satu unsur utama dalam program ini, kepada seluruh unsur lainnya yang ada di RSUP Prof. Dr. R. D. Kandou Manado. Sosialisasi juga dapat dikatakan sebagai langkah awal dari sebuah program, sehingga dapat menentukan keberhasilan program yang akan dijalankan. Sosialisasi juga harus dapat dilakukan dengan cermat dan efisien untuk mendapatkan hasil yang efektif dengan melihat kondisi dari sasaran sosialisasi, dalam hal ini lingkungan rumah sakit yang bisa dikatakan kompleks baik dari latar belakang pendidikan pegawainya, latar belakang profesi, tingkat pendidikan, dan karakter.

\section{Penutup}

Berdasarkan hasil analisis terhadap kendala-kendala yang dihadapi Satuan Pengawasan Internal pada pembangunan Zona Integritas di RSUP Prof. Dr. R. D. Kandou Manado serta upaya yang sudah dilakukan dalam mengatasi kendala tersebut seperti yang sudah dibahas dalam bab terdahulu, maka kesimpulan dari penelitian ini adalah bahwa masih banyak kendala yang dihadapi oleh Satuan Pengawasan Internal dalam membangun Zona Integritas, seperti kompetensi sumber daya manusia yang belum memadai untuk menjalankan tugas dan fungsi pengawasan dan pengendalian di rumah sakit, minimnya anggaran yang dialokasikan untuk pengembangan sumber daya manusia, lingkungan kerja yang cukup mempengaruhi kewenangan dan independensi SPI, kemudian juga permasalahan rangkap jabatan yang perlu mendapat perhatian khusus dari manajemen karena konsentrasi terhadap tugas SPI menjadi terganggu karena jabatan rangkap dari para personil SPI.

Dari penelitian ini juga dapat ditarik garis besar saran untuk jajaran manajemen rumah sakit untuk dapat segera mengalokasikan anggaran yang cukup dalam pengembangan sumber daya manusia guna meningkatkan kapabilitias personil SPI melalui pendidikan, seminar atau workshop terkait dengan pengawasan dan pengendalian internal termasuk pengetahuan di bidang audit.

\section{DAFTAR PUSTAKA}

Aprillia, Y. (2010). Analisis Sosialisasi Program Inisiasi Menyusu Dini dan ASI Eksklusif kepada Bidan di Kabupaten Klaten (Doctoral dissertation, Universitas Diponegoro).

Fatoni, Irfan dan Nurhayati, Dewi 2013, Pengaruh Anggaran dan Pengendalian Terhadap Efektivitas Kinerja Satuan Kerja Perangkat Daerah (SKPD) di Kabupaten Malang, Malang: Jurnal Manajemen dan Akuntansi, Volume 2 Nomor 3, Desember 2013.

Griffith, David.M. (2006), Modul: Risk Based Auditing: An Introduction, Version 4.4

Kewo, Cecilia Lelly, and Nunuy Nur Afiah. "PENGARUH PENGANGGARAN PARTISIPATIF, KEJELASAN SASARAN ANGGARAN DAN IMPLEMENTASI PENGENDALIAN INTERN TERHADAP KINERJA MANAJERIAL INSTANSI PEMERINTAH DAERAH SERTA IMPLIKASINYA PADA AKUNTABILITAS KEUANGAN." Seminar Nasional Akuntansi dan Bisnis (SNAB), Fakultas Ekonomi Universitas Widyatama, 2017 
Koentjaraningrat. 1993. Metode-metode Penelitian Masyarakat. (Edisi Ketiga). Jakarta: PT Gramedia Pustaka Utama.

Maulida, Riza (2015), Corporate Governance and Control: Dua tubuh satu kepala, rangkap jabatan petinggi BUMN, Makalah Tugas Akhir, Program Magister Akuntansi, Universitas Gajah Mada, Yogyakarta, Halaman 12

Sukriah, Ika (2012), Pengaruh Pengalaman Kerja, Independensi, Obyektifitas, Integritas dan Kompetensi Terhadap Kualitas Hasil Pemeriksaan, diambil dari http://blog.umy.ac.id/ervin/files/2012/06/aspsia13.pdf (04 Maret 2018)

Taufiqurrahman, (2014), Kebijakan Publik: Pendelegasian Tanggung Jawab Negara Kepada Presiden Selaku Penyelenggara Pemerintahan, Cetakan pertama, Jakarta: Beragama Pers Fakultas Ilmu Sosial Ilmu Politik Universitas Moestopo, Halaman 18

The Institute of Internal Auditors (2016), Global Advocacy Platform

Wahyudi, Amin. "Membangun Komitmen Organisasional untuk Meningkatkan Kinerja Dan Daya Saing Organisasi." Joglo 20.1 (2012)

Wang, Isabel (Zhe) and Neil Fargher (2014), The effects of tone at the top on Internal Auditors' Assessments of Financial Misstatements, Journal, The University of Western Australia and The Australian National Univerisy, Australia, Halaman 10 Committee of Sponsoring Organization (2013), Internal Control-Integrated Framework, ISBN 978-1-93735-239-4

Peraturan Menteri Kesehatan Nomor 6 Tahun 2015 tentang Kebijakan Pengawasan Inspektorat Jenderal Kementerian Kesehatan RI Tahun 2015 